\title{
Physiological maturity and drying speed in the quality of zucchini (Cucurbita pepo L.) seeds ${ }^{1}$
}

\author{
Hellismar Wakson da Silva ${ }^{2 *}$, João Almir Oliveira ${ }^{2}$, \\ Lucinda Helena Fragoso Monfort ${ }^{2}$, Jodson Moraes dos Santos², \\ Ana Clara Reis Trancoso ${ }^{2}$, Marcos Vinícios de Carvalho ${ }^{2}$
}

\begin{abstract}
Harvesting and drying are essential procedures to obtain high quality seeds as well as for their conservation during storage. The goal of this research was to identify the physiological maturity stage and to verify the effect of drying speeds on the quality of zucchini seeds. A completely randomized design in a $3 \times 2 \times 2$ factor scheme was used, involving three fruit maturation stages (49, 56 and 63 days after anthesis - DAA), two drying speeds (slow and quick) and two storage periods (0 and 6 months). Seed quality was evaluated by germination, first count, accelerated aging, electrical conductivity, tetrazolium, seedling emergence, emergence speed index and seed health test. Moisture content, thousand seed mass and percentage full seeds were also evaluated. Zucchini seeds reach maximum quality at 49 DAA. Slow or quick drying and storage do not affect the physiological quality of seeds that were harvested at 49 DAA. The delayed harvest of fruits reduces the quality of seeds. Quick drying reduces the incidence of the fungi Alternaria, Cladosporium, Phoma and Fusarium, and increases the occurrence of Aspergillus and Penicillium.
\end{abstract}

Index terms: Cucurbita pepo L., storage, deterioration, seed health test.

\section{Maturidade fisiológica e velocidade de secagem na qualidade de sementes de abobrinha (Cucurbita pepo L.)}

\begin{abstract}
RESUMO - A colheita e secagem são procedimentos essenciais para obtenção de sementes de elevada qualidade, bem como, para sua conservação durante o armazenamento. O objetivo nesta pesquisa foi identificar o estádio de maturidade fisiológica e verificar o efeito de velocidades de secagem sobre a qualidade de sementes de abobrinha. Utilizou-se o delineamento inteiramente casualizado em esquema fatorial 3x2x2, envolvendo três estádios de maturação de frutos (49, 56 e 63 dias após a antese - DAA), duas velocidades de secagem (lenta e rápida) e dois períodos de armazenamento ( 0 e 6 meses). A qualidade das sementes foi avaliada pelos testes de germinação, primeira contagem, envelhecimento acelerado, condutividade elétrica, tetrazólio, emergência de plântulas, índice de velocidade de emergência e sanidade. Também foi determinado o teor de água, massa de mil sementes e porcentagem de sementes cheias. As sementes de abobrinha atingem máxima qualidade aos 49 DAA. A secagem lenta e rápida e o armazenamento não influenciam a qualidade fisiológica das sementes colhidas aos 49 DAA. $\mathrm{O}$ atraso da colheita dos frutos reduz a qualidade das sementes. A secagem rápida reduz a incidência dos fungos Alternaria, Cladosporium, Fusarium e Phoma, e aumenta a ocorrência de Aspergillus e Penicillium.
\end{abstract}

Termos para indexação: Cucurbita pepo L., armazenamento, deterioração, sanidade.

\section{Introduction}

Zucchinis (Cucurbita pepo L.) belong to the Curcubitaceae family, the same as pumpkin, cackrey, watermelon, melon and cucumber (Filgueira, 2008). Its cultivation stands out in the national scenario as one out of the ten most economically important vegetable; most of the economic value of this culture derives from the commercialization of unripe fruits (Paris, 2016).

The growing concern of farmers about producing quality fruits for a market that is more and more demanding and,

\footnotetext{
${ }^{1}$ Submitted on 10/24/2016. Accepted for publication on 03/20/2017.

${ }^{2}$ Departamento de Agricultura, Universidade Federal de Lavras, Caixa Postal 3037, 37200-000 - Lavras, MG, Brasil.

*Corresponding author $<$ waksonhellismar@gmail.com>
} 
above all, about the fact that zucchini propagates exclusively by seeds, have increased the demand for high quality seeds. It is widely known that using seeds with a high physiological and sanitary quality is a basic element to obtain vigorous and even seedlings (Nakada et al., 2011) and, consequently, proper stands, higher productivity and better quality of the harvested product (Costa et al., 2008; Lopes et al., 2014).

The physiological maturity characterizes the stage where seeds reach their maximum dry matter, germination and vigor values (Marcos-Filho, 2015). Harvesting at this stage avoid obtaining unripe and drying-intolerant seeds, as well as the exposure of seeds on the field to biotic and abiotic factors that reduce their quality (Costa et al., 2006). Therefore, identifying the physiological maturity is essential to obtain seeds with high physiological and sanitary potential.

The practical recognition of the seed physiological maturity for curcubitaceae species has been performed based on morphological fruit markers (color of the epidermis) and on the number of days after anthesis (Medeiros et al., 2010; Marrocos et al., 2011; Nakada et al., 2011; Figueiredo Neto et al., 2014; Silva et al., 2015). However, due to the fact that zucchini plants present continuous flowering and fruits whose epidermis color has little alterations during maturation, the number of days after anthesis may be characterized as the most promising technique to identify the stage of maximum seed quality for this species.

In addition to the identification of the most proper moment to harvest, seed drying also has great importance in controlling the quality from producer companies, mainly for species whose seeds are harvested with high moisture contents (Queiroz et al., 2011), such as cackrey (50-60\%) (Medeiros et al., 2010), cucumber (33-38\%) (Nakada et al., 2011) and pumpkin (42\%) (Figueiredo Neto et al., 2014).

For fleshy fruit species, like cucumber (Nakada et al., 2010) and eggplant (Zamariola et al., 2013), whose seeds present high moisture content during and after they reach their physiological maturity, slow drying allows the development of tolerance mechanisms to water removal, resulting into better quality seeds (Marcos-Filho, 2015). On the other hand, the quick drying of seeds with elevated moisture content may cause oxidative processes and the production of free radicals, reducing seed quality (Queiroz et al., 2011).

The goal of this work was to identify the physiological maturity of zucchini seeds and to verify the effect of drying speeds over their quality during storage.

\section{Material and Methods}

The experiment was conducted at the Hortiagro Sementes Company, located in Ijaci - Minas Gerais state, and at the
"Laboratórios Central de Sementes' and "Patologia de Sementes" - University Federal of Lavras using zucchini (Cucurbita pepo L.) seeds from the Caserta variety.

The seeds from Hortiagro Sementes Company have been stored in a cool and dry chamber $\left(14.8{ }^{\circ} \mathrm{C}\right.$ and $54 \%$ air relative humidity - RH) for 12 months. Sowing was made in multi-cell trays containing commercial substrate. After 15 days from the sowing, seedlings were transplanted to seedbeds in a greenhouse, with $0.4 \mathrm{~m}$ between each plant and $1.2 \mathrm{~m}$ between each seedbed. Cultural treatments were performed according to the technical recommendations for the culture (Filgueira, 2008). The field experiment was conducted in the period between August and November 2015, whose average meteorological data obtained in the period were the following: Tmin $-16.7 \pm 2.3{ }^{\circ} \mathrm{C}$; T Tmax $29.1 \pm 2.8^{\circ} \mathrm{C}$; Taver $-22.0 \pm 2.3^{\circ} \mathrm{C}$; Photoperiod $-12.2 \pm 0.6$ hours.

During the reproductive stage of the culture, daily checks were performed and on the anthesis day, flowers were identified with woolen yarns with different colors (each color representing a day). Flowers remained open for approximately 12 hours, enabling visitations from pollinators and pollination standardization. Fruits coming from marked flowers were harvested manually at three maturation stages: 49 days after anthesis - DAA (yellow fruits with continuous dark green stripes), 56 DAA (yellow fruits with fragmented dark green and light yellow stripes) and 63 DAA (yellow fruits with fragmented dark green and dark yellow stripes). These maturation stages were defined because they encompassed the range of days after anthesis (45 to $60 \mathrm{DAA}$ ) recommended to harvest cucumber (Nakada et al., 2011), Menina Brasileira zucchini (Marrocos et al., 2011) and pumpkin (Silva et al., 2015) fruits, aiming at the obtainment of high quality seeds.

After harvesting, fruits were kept for seven days under environmental conditions of $25{ }^{\circ} \mathrm{C}$ and $80 \% \mathrm{RH}$ in order to uniform the maturation process, according to what was recommended for the species (Marrocos et al., 2011). After this resting period, seeds were extracted manually, washed under running water, centrifuged to remove the excess of water and submitted to drying; some were submitted to slow drying and some to quick drying. For the slow drying, seeds were distributed over plastic sheets and kept under environmental conditions of $23.7 \pm 1.5^{\circ} \mathrm{C}$ and $\left.80 \pm 5.6 \% \mathrm{RH}\right)$. The quick drying was conducted in the prototype of a stationary dryer (Navratil and Burris, 1982) at $35 \pm 2.1{ }^{\circ} \mathrm{C}$ and $40 \pm 4.6 \% \mathrm{RH}$. In the two drying procedures, seeds were distributed in a single layer and dried until reaching $9 \%$ of moisture content. After that, they went through an air machine and sieves, placed in multiwall kraft paper bags and stored at environmental conditions of $\mathrm{Tmin}-21.7 \pm 1.9^{\circ} \mathrm{C}$; T $\mathrm{Tmax}-$ $26.8 \pm 1.7{ }^{\circ} \mathrm{C}$; Taver $-24.0 \pm 1.6^{\circ} \mathrm{C}$; RHmin - 51.1 $\pm 3.5 \%$; RHmax $79.3 \pm 8.1 \%$; RHaver $-66.1 \pm 7.0 \%$. 
The experimental design was the completely randomized one, in a $3 \times 2 \times 2$ factor scheme, with four replications, namely three fruit maturation stages (49, 56 and 63 DAA), two drying speeds (slow and quick) and two storage periods (0 and 6 months). With the exception of the moisture content, the other tests, described as follows, were conducted using dry seeds ( $9 \%$ moisture content).

Moisture content $(M C)$ : it was determined after fruits maturation, extraction and centrifugation of the seeds, using the oven method at $105{ }^{\circ} \mathrm{C}$ for 24 hours (Brasil, 2009a), with four replications of 25 seeds.

Thousand seeds weight (TSW): eight replications of 100 seeds from the pure seed portion; they were weighed with a $0.001 \mathrm{~g}$ precision scale and the results were expressed in grams (Brasil, 2009a).

Germination $(G)$ and first count $(F C)$ : four replications of 25 seeds were sowed in towel paper rolls dampened with water equal to 2.5 times the weight of the dry paper and kept in a germinator regulated at the temperature of $25{ }^{\circ} \mathrm{C}$ and photoperiod of 8 hours. The percentage of normal seedlings was evaluated on the fourth (FC) and eighth (G) day after the seeding (Brasil, 2009a).

Accelerated aging (AA): the traditional method at $41{ }^{\circ} \mathrm{C}$ for 72 hours was used (Medeiros et al., 2014). After this period, four subsamples of 25 seeds were submitted to germination test, as described before, counting the percentage of normal seedlings on the fourth day after sowing.

Electrical conductivity (EC): conducted with four replications of 25 previously weighed seeds $(0.001 \mathrm{~g})$, placed in plastic cups with $75 \mathrm{~mL}$ of distilled water and kept in a B.O.D. at $25{ }^{\circ} \mathrm{C}$ for 24 hours. The electrical conductivity was evaluated with a mCA 150 model EC meter and the results were expressed in $\mu \mathrm{S} . \mathrm{cm}^{-1} \cdot \mathrm{g}^{-1}$ of seeds (Vieira and Krzyzanowski, 1999).

Tetrazolium test (TZ): pre-tests were performed with different methodologies, with higher effectiveness for the following procedures: pre-dampening of the seeds at $25{ }^{\circ} \mathrm{C}$ for 18 hours; longitudinal cut in the distal part of the embryonic axis and tegument removal; immersion of the embryos in water at $25^{\circ} \mathrm{C}$ for 3 hours to remove manually the thin membrane; and immersion of the embryos in a 2,3,5-triphenyl-tetrazolium chloride at $0.075 \%$ for 17 hours at $30{ }^{\circ} \mathrm{C}$. Subsequently, four subsamples of 25 embryos were washed under running water, sectioned longitudinally and evaluated as for viability (less than $50 \%$ of the cotyledons and, mainly, embryonic axis with dark pink color and tissues with normal, firm aspect) and vigor (cotyledons and embryonic axis with pink color and tissues with normal and firm aspect).

Radiographic analysis (RA): four replications of 100 seeds were exposed to radiation at a distance of $50 \mathrm{~cm}$ from a source in 43855A Faxitron HP device, with $26 \mathrm{kV}$ intensity for 18 seconds. The radiographic images were analyzed and the seeds were classified according with the internal structures; results were expressed in percentage of full seeds (embryo with more than $90 \%$ of developed tissues, clear and with no damages).

Seedling emergence (SE) and emergence speed index (ESI): they were conducted with four replications of 25 seeds, sowed in plastic trays containing soil and sand as substrate, in the 1:1 proportion. Trays were kept in a plant growth chamber, at the temperature of $25^{\circ} \mathrm{C}$ and daily regime of 12 light hours. Daily counts were performed after the emergence of the first seedling, registering the cotyledons that were completely out of the substrate, until stabilization. The percentage of emerged seedlings was determined at 15 after sowing and the emergence speed index was calculated according to Maguire (1962).

Seed health test (SH): eight replications of 25 seeds that were not treated with fungicide were incubated for 7 days under an alternate regime of light/dark for 12 hours, at the temperature of $20{ }^{\circ} \mathrm{C}$, according to the method of the filter paper (Blotter test). In order to reduce the germination speed of seeds, the substrate was dampened in a 2,4-D solution (sodium 2,4-dichlorophenoxyacetate) at a $8 \mathrm{ppm}$ concentration. After incubation, the incidence of fungi was evaluated in a stereoscopic microscope (Brasil, 2009b).

Data were submitted to analysis of variance using the statistic program Sisvar (Ferreira, 2011). Averages referring to the "maturation stage" factor were compared by Tukey's test $(\mathrm{p}<0.05)$. On the other hand, averages referring to "drying speed" and "storage period" factors were compared by F test $(\mathrm{p}<0.05)$.

\section{Results and Discussion}

There was a reduction in the moisture content of zucchini seeds with the increase in fruits' age, whose values varied from 37.44 to $34.13 \%$ (Table 1). In studies with cucumber and pumpkin, Nakada et al. (2011) and Silva et al. (2014) verified that the seeds reached their physiological maturity (45 and 60 DAA) with 33 and $41 \%$ of moisture content, respectively. The high moisture content of seeds is necessary to have the proper synthesis and accumulation of stock materials (Marrocos et al., 2011). However, when reaching physiological maturity, seeds must be immediately submitted to drying, in order to reduce the high moisture content and, consequently, avoid immediate damages coming from fermentation (Nakada et al., 2010).

The delayed harvest of fruits did not cause significant variations in the thousand seed weight (Table 1), highlighting 
that at 49 DAA seeds had already reached their maximum stock accumulation. For Menina Brasileira zucchini seeds, the maximum stock accumulation was observed between 50 and 60 DAA (Marrocos et al., 2011), supporting the results of this work.

It is known that regardless of the maturation stage of fruits, the percentage of full seeds was close to $100 \%$ (Table 1), demonstrating the complete formation of the internal structures of seeds. It was observed that the percentage of full seeds was related to germination, whose results were above $96 \%$ for nonstored seeds (Table 2). Working with pumpkin seeds collected between 30 and 60 DAA, Silva et al. (2014) verified that the progress of the maturation stage of fruits increased considerably the percentage of full seeds, relating with the percentage of normal seedlings. When harvesting cucumber fruits between 30 and 55 DAA, Nakada et al. (2011) also verified an increase in the percentage of full seeds with the maturation of fruits, coinciding with the increase of normal seedlings and vigor (electrical conductivity and emergence speed index).

Through germination results, it is possible to observe that for seeds harvested at 49 and 56 DAA and stored for zero and six months, respectively, quick drying was significantly superior than slow drying (Table 2). As for seeds that were dried slowly, at the sixth storage month there was lower germination for seeds that were harvested at 56 DAA, differing statistically from the ones harvested at 49 DAA and stored for sixth months.

In studies with eggplant seeds, Zamariola et al. (2013) verified that on month 0 and 6 of storage, there was no germination difference for seeds submitted to slow $\left(25^{\circ} \mathrm{C}\right)$ and quick $\left(35^{\circ} \mathrm{C}\right)$ drying. When submitting cucumber seeds to drying at 25,35 and $45^{\circ} \mathrm{C}$, Nakada et al. (2010) also did not observe differences in the germination potential, whose values remained above $94 \%$ even after twelve months of storage at environmental conditions.

In spite of the fact that germination has been substantially preserved for six months of storage under non-controlled conditions, there was a reduction in the first count during storage (Table 3). Similar results were observed by Nakada et al. (2010), where the germination of cucumber seeds harvested at 45 DAA reduced gradually after six months of storage under non-controlled conditions.

The germination percentage in the first count decreased with the delayed harvest, highlighting that the maximum quality of zucchini seeds was reached at 49 DAA (Table 3 ). As for the Menina Brasileira zucchini, Marrocos et al. (2011) observed that the physiological maturity of seeds was reached between 50 and 60 DAA. As for pumpkin, Figueiredo Neto et al. (2014) and Figueiredo Neto et al. (2015) verified that the maximum quality of seeds was reached at 50 DAA.

Comparing the maturation stages of fruits, it was observed that seeds submitted to slow drying did not present variations as for vigor, estimated by the accelerated aging test (Table 4). However, seeds harvested at 63 DAA and submitted to quick

Table 1. Moisture content (MC), thousand seed weight (TSW) and full seeds (FS) of zucchini (Cucurbita pepo L.) seeds, in different fruit maturation stages (49, 56 and 63 DAA).

\begin{tabular}{cccc}
\hline Maturation stages & MC (\%) & TSW $(\mathrm{g})$ & FS (\%) \\
\hline 49 DAA & $37.44 \mathrm{a}$ & $151.07 \mathrm{a}$ & $98 \mathrm{a}$ \\
56 DAA & $34.64 \mathrm{~b}$ & $150.06 \mathrm{a}$ & $97 \mathrm{a}$ \\
63 DAA & $34.13 \mathrm{~b}$ & $150.47 \mathrm{a}$ & $97 \mathrm{a}$ \\
\hline CV $(\%)$ & 4.32 & 2.07 & 2.48 \\
\hline
\end{tabular}

Averages followed by the same letter in the column do not differ among themselves by Tukey's test $(\mathrm{p}<0.05)$.

Table 2. Germination (\%) of zucchini (Cucurbita pepo L.) seeds, in different fruit maturation stages $(49,56$ and 63 DAA), drying speeds (SD: slow drying and QD: quick drying) and storage times (0 and 6 months).

\begin{tabular}{ccrrr}
\hline \multirow{2}{*}{ Maturation stages } & \multicolumn{2}{c}{0 months } & \multicolumn{2}{c}{6 months } \\
\cline { 2 - 5 } & SD & QD & SD & \multicolumn{1}{c}{ QD } \\
\hline 49 DAA & $96 \mathrm{aB}$ & $100 \mathrm{aA}$ & $97 \mathrm{aA}$ & $99 \mathrm{aA}$ \\
$56 \mathrm{DAA}$ & $98 \mathrm{aA}$ & $98 \mathrm{aA}$ & $92 \mathrm{bB}$ & $100 \mathrm{aA}$ \\
$63 \mathrm{DAA}$ & $99 \mathrm{aA}$ & $99 \mathrm{aA}$ & $96 \mathrm{abA}$ & $96 \mathrm{aA}$ \\
\hline CV (\%) & \multicolumn{4}{c}{2.65} \\
\hline
\end{tabular}

Averages followed by the same lowercase letter in the column do not differ among themselves by Tukey's test $(\mathrm{p}<0.05)$. Averages followed by the same capital letter on the line, in each storage time, do not differ among themselves by F test $(\mathrm{p}<0.05)$.

Table 3. Germination first count (\%) of zucchini (Cucurbita pepo L.) seeds, in different fruit maturation stages $(49,56$ and 63 DAA) and storage times (0 and 6 months).

\begin{tabular}{cccc}
\hline Maturation stages & 0 months & 6 months & Average \\
\hline 49 DAA & 96 & 91 & $93 \mathrm{a}$ \\
56 DAA & 94 & 85 & $89 \mathrm{ab}$ \\
63 DAA & 85 & 85 & $85 \mathrm{~b}$ \\
\hline Average & $91 \mathrm{~A}$ & $87 \mathrm{~B}$ \\
\hline CV $(\%)$ & \multicolumn{3}{c}{6.11}
\end{tabular}

Averages followed by the same lowercase letter in the column do not differ among themselves by Tukey's test $(p<0.05)$. Averages followed by the same capital letter on the line do not differ among themselves by $F$ test $(p<0.05)$. 
drying presented lower vigor than the ones harvested at 49 and 53 DAA, also differing from the seeds submitted to slow drying. These results demonstrated again that seeds reached maximum vigor at $49 \mathrm{DAA}$, as well as that the delayed harvest of fruits and the later quick drying reduce the quality of seeds.

Based on the results of the tetrazolium test, it was verified that regardless of the maturation stage of fruits, seeds presented $100 \%$ viability (Table 5). However, when classifying seeds as for their vigor by the same test, it was observed that at 49 DAA, seeds presented higher vigor (90\%), which decreased significantly at $63 \mathrm{DAA}(86 \%)$. This negative effect of delaying the harvest on the quality of seeds was also observed in the germination first count (Table 3), and in the accelerated aging (Table 4).

For the electrical conductivity test, values decreased with the increase in fruits' age for both drying speeds, with lower values for the slow drying at 49 and 56 DAA, when compared to the quick drying (Table 6). In studies with cucumber, Nakada et al. (2010) verified that compared with the $45^{\circ} \mathrm{C}$ temperature, seeds dried at room temperature $\left(25^{\circ} \mathrm{C}\right)$ and at $35^{\circ} \mathrm{C}$ presented lower electrical conductivity values, ascribing this behavior to the longer drying time observed at lower temperatures. According to Silva et al. (2007), slow drying promotes better tolerance to water removal, possibly due to the longer time demanded to induce and operate defense mechanisms.

The average time needed by zucchini seeds to reach $9 \%$ of moisture content was approximately 7 days (drying speed: $0.16 \% \mathrm{~h}^{-1}$ ) for the slow drying and 19 hours (drying speed: $\left.1.39 \% \mathrm{~h}^{-1}\right)$ for the quick drying $\left(35^{\circ} \mathrm{C}\right)$. Therefore, it is possible that the lower electrical conductivity values of seeds submitted to slow drying indicates that a longer dry time has enabled better restoring of the cell membrane systems, reducing considerably the quantity of released leachates.

It is important to highlight that the decrease in the electrical conductivity with the increase of fruits age did not characterize any increase in the seed vigor, since these results did not provide compatible information with the other vigor tests (Tables 3, 4, 5 and 7), where the quality of seeds decreased gradually with the delayed harvest. It is worth highlighting that according to Elias et al. (2012), the electrical conductivity test is not effective to evaluate the vigor of seeds from all cultures, since generally the presence of a semipermeable membrane with nuclear origin allows the inlet of water, but not the diffusion of certain electrolytes outside the cell. This behavior was also observed for zucchini (Dutra and Vieira, 2006) and melon (Torres et al., 2009) seeds, where the electrical conductivity did not present compatible results with the ones from the other vigor tests.

When analyzing the results of the emergence test and the emergence speed index of seedlings (Table 7), it was observed that regardless of the storage time, the quality of seeds was maximum at 49 DAA, without any difference between the drying speeds. However, starting from this maturation stage, the quality of seeds submitted to quick drying reduced drastically in both storage times (0 and 6 months), with statistically lower values than the slow drying ones, where emergence and emergence speed index remained constant in the three maturation stages and over the storage of seeds.

Table 4. Germination (\%) of zucchini (Cucurbita pepo L.) seeds after accelerated aging, in different fruit maturation stages (49, 56 and 63 DAA) and drying speeds (SD: slow drying and QD: quick drying).

\begin{tabular}{ccc}
\hline Maturation stages & SD & QD \\
\hline 49 DAA & $86 \mathrm{aA}$ & $87 \mathrm{aA}$ \\
56 DAA & $85 \mathrm{aA}$ & $86 \mathrm{aA}$ \\
63 DAA & $84 \mathrm{aA}$ & $74 \mathrm{bB}$ \\
\hline CV $(\%)$ & \multicolumn{3}{c}{8.80} \\
\hline
\end{tabular}

Averages followed by the same lowercase letter in the column do not differ among themselves by Tukey's test $(\mathrm{p}<0.05)$. Averages followed by the same capital letter on the line do not differ among themselves by $F$ test $(p<0.05)$.

Table 5. Viability and vigor of zucchini (Cucurbita pepo L.) seeds by tetrazolium test, in different fruit maturation stages (49, 56 and 63 DAA).

\begin{tabular}{ccc}
\hline Maturation stages & Viability (\%) & Vigor (\%) \\
\hline 49 DAA & 100 & $90 \mathrm{a}$ \\
56 DAA & 100 & $89 \mathrm{ab}$ \\
63 DAA & 100 & $86 \mathrm{~b}$ \\
\hline CV (\%) & 2.09 & 3.95 \\
\hline
\end{tabular}

Averages followed by the same lowercase letter in the column do not differ among themselves by Tukey's test $(\mathrm{p}<0.05)$.

Table 6. Electrical conductivity $\left(\mu \cdot \mathrm{cm}^{-1} \cdot \mathrm{g}^{-1}\right)$ of zucchini (Cucurbita pepo L.), in different fruit maturation stages (49, 56 and 63 DAA) and drying speeds (SD: slow drying and QD: quick drying).

\begin{tabular}{ccc}
\hline Maturation stages & SD & QD \\
\hline 49 DAA & $36.76 \mathrm{aB}$ & $44.30 \mathrm{aA}$ \\
56 DAA & $25.25 \mathrm{bB}$ & $29.11 \mathrm{bA}$ \\
63 DAA & $15.24 \mathrm{cA}$ & $17.35 \mathrm{cA}$ \\
\hline CV $(\%)$ & \multicolumn{3}{c}{7.69} \\
\hline
\end{tabular}

Averages followed by the same lowercase letter in the column do not differ among themselves by Tukey's test $(\mathrm{p}<0.05)$. Averages followed by the same capital letter on the line do not differ among themselves by $F$ test $(p<0.05)$. 
Zamariola et al. (2013) verified that compared with slow drying $\left(25^{\circ} \mathrm{C}\right)$, quick drying $\left(35^{\circ} \mathrm{C}\right)$ reduced the percentage of emergence and the emergence speed index of eggplant seed seedlings, agreeing with the results obtained in this work. Again with eggplant seeds, França et al. (2013) observed that the increase in the drying temperature from $32{ }^{\circ} \mathrm{C}$ to $38{ }^{\circ} \mathrm{C}$ reduced seedling emergence from 93 to $77 \%$.

When reaching physiological maturity and becoming independent from the mother plant, there is the start of a series of physiological and biochemical alterations that result into the gradual reduction of the germination and culminate in the death of the seed (Marcos-Filho, 2015). Therefore, it is evident that the decrease in the zucchini seed quality starting from day 49 DAA indicates the beginning of the deterioration, as well as characterizing this stage as the moment when the physiological maturity occurs, that is, the period when maxim values of stock, germination and vigor were observed.

When analyzing the sanitary quality of seeds (Figure 1), it was possible to observe higher occurrence of the following fungi genera: Alternaria, Penicillium, Cladosporium, Aspergillus, Fusarium and Phoma.

In seeds of Menina Brasileira pumpkin, Casaroli et al. (2006) observed the presence of the fungi Alternaria, Penicillium, Cladosporium, Aspergillus, Fusarium and Phoma, which did not interfere in the physiological quality of seeds. With the exception of Cladosporium, Bee and Barros (1999) also detected these fungi genera in seeds of the Caserta pumpkin variety.

Generally speaking, the incidence of Alternaria, Cladosporium, Fusarium and Phoma was lower for seeds submitted to quick drying, both for newly-harvested seeds and for the stored ones (Figure 1). However, the incidence of Penicillium and Aspergillus was lower in slowly dried seeds, whose values remained below $2 \%$, regardless of the storage time. Nakada et al. (2010), also verified lower incidence of Aspergillus and Penicillium in cucumber seeds that were dried at room temperature $\left(25^{\circ} \mathrm{C}\right)$. For this drying temperature, the incidence of Fusarium in cucumber seeds was higher compared to drying at 35 and $45^{\circ} \mathrm{C}$, agreeing with the results obtained in the present work. Alternaria, Cladosporium, Fusarium and Phoma are classified as field fungi and may be transmitted to seedlings and plants via seed (Casaroli et al., 2006). Therefore, it is possible that the contamination of seeds has occurred in the production field itself, as well as the longer exposure time of seeds to humidity during drying may have favored the proliferation and, consequently, the higher incidence of these fungi.

The association of Aspergillus and Penicillium to seeds may be highly detrimental to their physiological quality, causing germination loss, rotting, heating of the seed mass and production of mycotoxins (Machado, 2012). However, it is possible to observe that generally speaking, there was a reduction in the incidence of Penicillium and an increase in the incidence of Aspergillus during storage, as also observed for pumpkin (Bee and Barros, 1999) and cucumber seeds

Table 7. Seedling emergence and emergence speed index of zucchini (Cucurbita pepo L.) seedlings, in different fruit maturation stages $(49,56$ and 63 DAA), drying speeds (SD: slow drying and QD: quick drying) and storage times ( 0 and 6 months).

\begin{tabular}{ccccc}
\hline \multirow{2}{*}{ Maturation stages } & \multicolumn{2}{c}{0 months } & \multicolumn{2}{c}{6 months } \\
\cline { 2 - 5 } & SD & QD & SD & QD \\
\hline \multicolumn{5}{c}{ Seedling emergence (\%) } \\
\hline 49 DAA & $99 \mathrm{aA}$ & $93 \mathrm{aA}$ & $99 \mathrm{aA}$ & $94 \mathrm{aA}$ \\
$56 \mathrm{DAA}$ & $96 \mathrm{aA}$ & $63 \mathrm{bB}$ & $88 \mathrm{aA}$ & $76 \mathrm{bB}$ \\
$63 \mathrm{DAA}$ & $93 \mathrm{aA}$ & $56 \mathrm{bB}$ & $91 \mathrm{aA}$ & $75 \mathrm{bB}$ \\
\hline CV (\%) & \multicolumn{5}{c}{7.75} \\
\hline Emergence speed index \\
\hline 56 DAA & $5.41 \mathrm{aA}$ & $4.76 \mathrm{aA}$ & $4.79 \mathrm{aA}$ & $4.15 \mathrm{aA}$ \\
$63 \mathrm{DAA}$ & $5.34 \mathrm{aA}$ & $2.69 \mathrm{bB}$ & $4.19 \mathrm{aA}$ & $3.18 \mathrm{bB}$ \\
CV (\%) & $5.32 \mathrm{aA}$ & $2.57 \mathrm{bB}$ & $4.38 \mathrm{aA}$ & $3.11 \mathrm{bB}$ \\
\hline \multicolumn{5}{c}{11.45} \\
\hline
\end{tabular}

$\overline{\text { Averages followed by the same lowercase letter in the column do not differ }}$ among themselves by Tukey's test $(p<0.05)$. Averages followed by the same capital letter on the line, in each storage time, do not differ among themselves by $\mathrm{F}$ test $(\mathrm{p}<0.05)$.

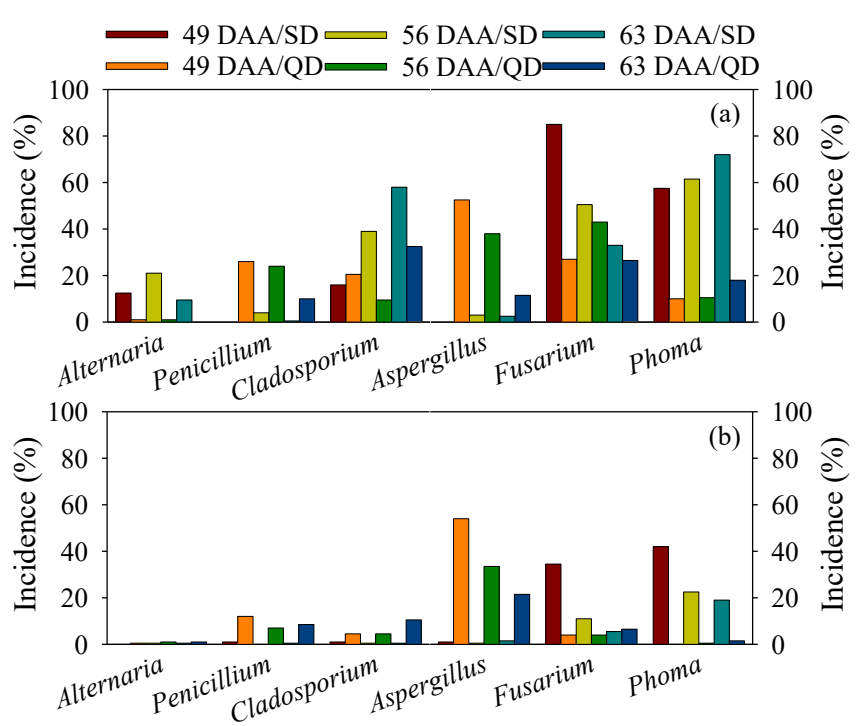

Figure 1. Incidence of fungi according to the maturation stage of fruits (49, 56 and $63 \mathrm{DAA})$, drying speed (SD: slow drying and QD: quick drying) and storage times ( 0 and 6 months, "a" and "b" respectively) of zucchini (Cucurbita pepo L.) seeds. 
(Nakada et al., 2010).

It is possible to highlight that, probably, the climate conditions during the storage time and the low moisture content of seeds $(9 \%)$ have been unfavorable to the development of Aspergillus and Penicillium, since these fungi present low incidence.

When comparing the incidence of fungi in the different maturation stages of fruits, it was observed that the delayed harvest considerably increased the occurrence of Cladosporium and Phoma in newly harvested seeds, but on the sixth month of storage, there was a decrease in the percentage of seeds infested by the latter. On the other hand, it was observed that, generally speaking, a delayed harvest helped the reduction in the incidence of Alternaria, Fusarium, Penicillium and, mainly, Aspergillus.

Regardless of the studied maturation stage of fruits and drying speeds, the incidence of fungi was higher in newly harvested seeds than in stored ones, with the exception of Aspergillus. However, it was not possible to establish a relation between sanitary and physiological quality, since the incidence of fungi did not interfere in the germination percentage and the performance of seedlings, agreeing with the results obtained by Bee and Barros (1999) and Casaroli et al. (2006), both working with pumpkin seeds.

\section{Conclusions}

Harvesting zucchini fruits at 49 DAA enables obtaining seeds with high physiological potential.

The physiological quality is not influenced by the drying speed of seeds when collected at 49 DAA.

A delayed harvest of fruits reduces the physiological quality of seeds.

The physiological quality of seeds that were harvested at 49 DAA is maintained during six months of storage.

Quick drying reduces the incidence of the fungi Alternaria, Cladosporium, Fusarium and Phoma, and increases the occurrence of Aspergillus and Penicillium.

\section{Acknowledgments}

To the Coordenação de Aperfeiçoamento de Pessoal de Nível Superior (CAPES), the Conselho Nacional de Desenvolvimento Científico e Tecnológico (CNPq), the Fundação de Amparo à Pesquisa do Estado de Minas Gerais (FAPEMIG) and the company Hortiagro Sementes for the financial and technical support in this research.
BEE, R.A.; BARROS, A.C.S.A. Sementes de abóbora armazenadas em condições de vácuo. Revista Brasileira de Sementes, v.21, n.2, p.120-126, 1999. http://www.abrates.org.br/revista/artigos/1999/v21n2/artigo19.pdf

BRASIL. Ministério da Agricultura Pecuária e Abastecimento. Regras para análise de sementes. Ministério da Agricultura Pecuária e Abastecimento. Secretaria Nacional de Defesa Agropecuária. Brasília: MAPA, 2009a. 395p. http://www.agricultura.gov.br/arq editor/file/2946_regras_analise_sementes.pdf

BRASIL. Ministério da Agricultura e Reforma Agrária. Manual de análise sanitária de sementes. Ministério da Agricultura Pecuária e Abastecimento. Secretaria Nacional de Defesa Agropecuária. Brasília: MAPA, 2009b. 200p. http://www.agricultura.gov.br/arq editor/file/12261 sementes_-web.pdf

CASAROLI, D.; GARCIA, D.C.; MUNIZ, M.F.B.; MENEZES, N.L. Qualidade sanitária e fisiológica de sementes de abóbora variedade Menina Brasileira. Fitopatologia Brasileira, v.31, n.2, p.158-163, 2006. http://www.scielo.br/scielo.php?script=sci arttext\&pid=S0100-41582006000200006

COSTA, C.J.; TRZECIAK, M.B.; VILLELA, F.A. Potencial fisiológico desementes debrássicas comênfasenotestede envelhecimentoacelerado. Horticultura Brasileira, v.26, n.2, p.144-148, 2008. http://www.scielo. br/scielo.php?script=sci_arttext\&pid=S0102-05362008000200003

COSTA, C.J.; CARMONA, R.; NASCIMENTO, W.M. Idade e tempo de armazenamento de frutos e qualidade fisiológica de sementes de abóbora híbrida. Revista Brasileira de Sementes, v.28, n.1, p.127-132, 2006. http://www.scielo.br/scielo.php?script=sci arttext\&pid=S0101-31222006000100018

DUTRA, A.S.; VIEIRA, R.D. Teste de condutividade elétrica para a avaliação do vigor de sementes de abobrinha. Revista Brasileira de Sementes, v.28, n.2, p.147-151, 2006. http://www.scielo.br/scielo. php?script=sci_arttext\&pid=S0101-31222006000200015

ELIAS, S.G.; COPELAND, L.O.; McDONALD, M.B.; BAALBAKI, R.Z. Seed testing: principles and practices. East Lansing: Michigan State University Press, 2012. 354p.

FERREIRA, D.F. Sisvar: a computer statistical analysis system. Ciência e Agrotecnologia, v.35, n.6, p.1039-1042, 2011. http://www. scielo.br/scielo.php?pid=S141370542011000600001\&script $=$ sci

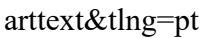

FIGUEIREDO NETO, A.; ALMEIDA, F.A.C.; VIEIRA, J.F.; SILVA, M.F. Physiological maturity of pumpkin seeds. African Journal of Agricultural Research, v.11, n.39, p.3733-3740, 2015. http://www. academicjournals.org/journal/AJAR/article-abstract/F215FF753870

FIGUEIREDO NETO, A.; ALMEIDA, F.A.C.; DANTAS, B.F.; GARRIDO, M.S.; ARAGÃO, C.A. Maturação fisiológica de sementes de abóbora (Curcubita moschata Duch) produzidas no semiárido. Comunicata Scientiae, v.5, n.3, p.302-310, 2014. https:// comunicatascientiae.com.br/comunicata/article/view/552/257

FILGUEIRA, F.A.R. Novo manual de olericultura: agrotecnologia moderna na produção e comercialização de hortaliças. Viçosa: UFV, 2008. $421 \mathrm{p}$

\section{References}


FRANÇA, L.V.; CRODA, M.D.; NASCIMENTO, W.M.; FREITAS, R.A.D. Physiological quality of eggplant seeds with different extraction and drying methods. Journal of Seed Science, v.35, n.1, p.51-55, 2013. http://www.scielo.br/scielo.php?script=sci_ arttext\&pid=S2317-15372013000100007

LOPES, K.P.; NASCIMENTO, M.D.G.R.; BARBOSA, R.C.A.; COSTA, C.C. Salinidade na qualidade fsiológica em sementes de Brassica oleracea L. var. itálica. Semina: Ciências Agrárias, v.35, n.5, p.2251-2260, 2014. http://www.uel.br/revistas/uel/index.php/ semagrarias/article/view/11266

MACHADO, J.C. Patologia de sementes: significado e atribuiões. IN: CARVALHO, N.M.; NAKAGAWA, J. (Eds.) Sementes: ciência, tecnologia e produção. Jaboticabal: FUNEP, 2012. p.524-590.

MAGUIRE, J.D. Speed of germination: aid in selection and evaluation for seedling emergence and vigour. Crop Science, v.2, n.2, p.176-177, 1962. https://dl.sciencesocieties.org/publications/cs/ abstracts/2/2/CS0020020176

MARCOS-FILHO, J. Fisiologia de sementes de plantas cultivadas. Londrina: ABRATES, 2015. 660p.

MARROCOS, S.T.P.; MEDEIROS, M.A.; GRANGEIRO, L.C.; TORRES, S.B.; LUCENA, R.R.M. Maturação de sementes de abobrinha menina brasileira. Revista Brasileira de Sementes, v.33, n.2, p.272-278, 2011. http://www.scielo.br/scielo.php?script=sci_ arttext\&pid=S0101-31222011000200009

MEDEIROS, M.A.; GRANGEIRO, L.C.; TORRES, S.B.; FREITAS, A.V.L. Maturação fisiológica de sementes de maxixe (Cucumis anguria L.). Revista Brasileira de Sementes, v.32, n.3, p. 17-24, 2010. http://www.scielo.br/scielo.php?script=sci arttext\&pid=S0101-31222010000300002

MEDEIROS, M.A.; TORRES, S.B.; NEGREIROS, M.Z.; MADALENA, J.A.S. Testes de estresse térmico em sementes de melão. Revista Brasileira de Ciências Agrárias, v.35, n.5, p.2251-2260, 2014. http://www.agraria.pro.br/sistema/index.php?journal=agraria \& page $=$ article \& o p = view \& path $\% 5$ B \% 5 D = agraria v9ila2393\&path $\% 5 B \% 5 \mathrm{D}=1514$

NAKADA, P.G.; OLIVEIRA, J.A.; MELO, L.C.; GOMES, L.A.A.; VON PINHO, E.V.R. Desempenho fisiológico e bioquímico de sementes de pepino nos diferentes estádios de maturação. Revista Brasileira de Sementes, v.33, n.1, p.113-122, 2011. http://www.scielo.br/scielo.php?script=sci_arttext\&pid=S0101$31222011000100013 \& \operatorname{lng}=$ en\&nrm $=$ iso\&tlng $=$ pt

NAKADA,P.G.;OLIVEIRA, J.A.;MELO,L.C.; SILVA,A.S.; SILVA, P.A.;PERINA,F.J.Desempenhoduranteoarmazenamentodesementes de pepino submetidas a diferentes métodos de secagem. Revista Brasileira de Sementes, v.32, n.3, p.42-51, 2010. http://www.scielo. $\mathrm{br} /$ scielo.php? script $=$ sci_arttext\&pid $=\mathrm{S} 0101-31222011000100$ $013 \& \operatorname{lng}=$ en $\&$ nrm $=$ iso \& $\operatorname{tn} g=$ pt
NAVRATIL, R. J.;BURRIS, J. S. Small-scalle dryer design. Agronomy Journal, v.74, n.1, p. 159-161, 1982. https://dl.sciencesocieties.org/ publications/aj/abstracts/74/1/AJ0740010159

PARIS, H.S. Germplasm enhancement of Cucurbita pepo (pumpkin, squash, gourd: Cucurbitaceae): progress and challenges. Euphytica, v.208, n.3, p.415-438, 2016. http://link.springer.com/article/10.1007/ s10681-015-1605-y

QUEIROZ,L.A.F.; VON PINHO,E.V.R.; OLIVEIRA, J.A.; FERREIRA, V.F.; CARVALHO, B.O.; BUENO, A.C.R. Época de colheita e secagem na qualidade de sementes de pimenta Habanero Yellow. Revista Brasileira de Sementes, v.33, n.3, p.472-481, 2011. http://www.scielo.br/scielo. php?script=sci_arttext\&pid=S0101-31222011000300010

SILVA, P.D.A.; DINIZ, K.A.; OLIVEIRA, J.A.; VON PINHO, E.V.R. Análise fisiológica e ultra-estrutural durante o desenvolvimento e a secagem de sementes de soja. Revista Brasileira de Sementes, v.29, n.2, p.15-22, 2007. http://www.scielo.br/scielo.php?script=sci arttext\&pid $=$ S0101-31222007000200003

SILVA, P.P.; BARROS, A.C.S.A.; VON PINHO, E.V.R.; NASCIMENTO, W.M. Physiological analysis and heat-resistant protein (LEA) activity in squash hybrid seeds during development. Journal of Seed Science, v.37, n.4, p.185-191,2015.http://www.scielo. br/scielo.php?script $=$ sci_arttext\&pid=S2317-15372015000400185

SILVA, P.P.; FREITAS, R.A.; CÍCERO, S.M.; MARCOS-FILHO, J.; NASCIMENTO, W.M. Análise de imagens no estudo morfológico e fisiológico de sementes de abóbora. Horticultura Brasileira, v.32, n.2, p.210-214, 2014. http://www.scielo.br/scielo.php?script=sci arttext\&pid=S010205362014000200210\&lng=en\&nrm=iso

TORRES, S.B.; OLIVEIRA, F.N.; OLIVEIRA, A.K.; BENEDITO, C.P.; MARINHO, J.C. Envelhecimento acelerado para avaliação do potencial fisiológico de sementes de melão. Horticultura Brasileira, v.27, n.1, p.70-75, 2009. http://www.scielo.br/scielo.php?script=sci arttext\&pid=S0102-05362009000100014

VIEIRA, R.D.; KRZYZANOWSKI, F.C. Teste de condutividade elétrica. IN: KRZYZANOWSKI, F.C.; VIEIRA, R.D.; FRANÇANETO, J.B. (Ed.). Vigor de sementes: conceitos e testes. Londrina: ABRATES, 1999. p.4.1-4.26.

ZAMARIOLA, N.; OLIVEIRA, J.A.; GOMES, L.A.A.; JÁCOME, M.F.; REIS, L.V. Effect of drying, pelliculation and storage on the physiological quality of eggplant seeds. Journal of Seed Science, v.36, n.2, p.240-245, 2013. http://www.scielo.br/scielo. php?script=sci_arttext\&pid=S2317-15372014000200013 